\title{
Effects of the $\mathrm{CRF}_{1}$ receptor antagonist SSR125543 on energy balance and food deprivation-induced neuronal activation in obese Zucker rats
}

\author{
Christian Doyon, Pierre Samson, Josée Lalonde and Denis Richard \\ Chaire de recherche Merck Frosst/IRSC sur l'obésité and Centre de recherche de l'Hôpital Laval, Hôpital Laval, 2725 chemin Sainte-Foy, Québec, \\ Canada G1V 4G5 \\ (Requests for offprints should be addressed to D Richard; Email: denis.richard@crhl.ulaval.ca) \\ (The present address of C Doyon is the Department of Cellular and Molecular Medicine, Faculty of Medicine, University of Ottawa, Ottawa, Canada K1H 8M5)
}

\begin{abstract}
The corticotropin-releasing factor (CRF) system is involved in numerous physiological and behavioral actions, including the regulation of energy balance. We examined the effects of the $\mathrm{CRF}_{1}$ receptor antagonist, SSR 125543, on energy balance and food deprivation-induced neuronal activation in obese rats. Lean $(\mathrm{Fa} /$ ? $)$ and obese $(f a / f a)$ Zucker rats were treated orally with SSR 125543 at a daily dose of $30 \mathrm{mg} / \mathrm{kg}$ for 21 days. Rats were killed either fed ad libitum or food deprived for $6 \mathrm{~h}$ in order to induce a mild stress response in obese rats. SSR 125543 reduced plasma corticosterone levels in lean rats, prevented corticosterone response to fasting in obese rats, and increased CRF mRNA levels in the paraventricular hypothalamic nucleus (PVN) of both lean and obese rats, further confirming that the antagonist partially blocked $\mathrm{CRF}_{1}$ receptors. SSR 125543 increased protein gain in obese rats. Whole carcass analyses

showed reduced energy and fat gains in lean rats. Consistent with reduced fat gain, circulating triglyceride and leptin levels were reduced in SSR125543-treated lean rats. In obese rats, circulating glucose levels and the homeostasis model assessment of insulin resistance index of insulin resistance were reduced by SSR125543 treatment. CRF 1 receptor blockade increased uncoupling protein-1 mRNA levels in interscapular brown adipose tissue of obese rats. The antagonist partly blocked the fasting-induced changes in c-fos mRNA levels in the PVN and arcuate nucleus of obese rats. Overall, these results suggest that although SSR125543 had relatively mild effects on energy balance, $\mathrm{CRF}_{1}$ receptor blockade attenuated several metabolic effects of short-term fasting and improved plasma variables related to the metabolic syndrome and diabetes.

Journal of Endocrinology (2007) 193, 11-19
\end{abstract}

\section{Introduction}

The corticotropin-releasing factor (CRF) family of peptides produce a global negative energy profile by reducing food intake and increasing energy expenditure (Richard et al. 2002, Doyon et al. 2004). The effects of CRF-related peptides on energy expenditure are thought to depend on a $\mathrm{CRF}_{1}$ receptor-mediated activation of thermogenesis. Central administration of CRF or urocortin 1 stimulated thermogenesis in brown adipose tissue (BAT), possibly through a sympathetically mediated process (LeFeuvre et al. 1987, Arase et al. 1988, Currie et al. 2001, De Fanti \& Martínez 2002). However, prolonged $\mathrm{CRF}_{1}$ receptor activation could also produce non-specific effects on energy expenditure that would oppose those of CRF-related peptides. For instance, the stimulation of $\mathrm{CRF}_{1}$ receptors strongly activates the pituitaryadrenal axis and the secretion of corticosteroids, which, by contrast to CRF, promote energy deposition (Castonguay et al. 1986, Strack et al. 1995) and inhibit BAT thermogenesis (Galpin et al. 1983, Strack et al. 1995, Arvaniti et al. 1998).

The role of the $\mathrm{CRF}_{1}$ receptor in feeding behavior remains unclear (Heinrichs \& Richard 1999). Administration of the selective $\mathrm{CRF}_{1}$ receptor antagonist NBI-27914 did not attenuate the CRF-induced reduction in food intake (Smagin et al. 1998, Pelleymounter et al. 2000), and sub-chronic administration of CRA1000 did not affect food intake and body weight (Ohata et al. 2002). However, CRA1000 blocked anorexia induced by emotional stress (Hotta et al. 1999). This result supports the idea that $\mathrm{CRF}_{1}$ receptor could mediate anorectic effects that would be non-specific and secondary to the anxiety- and fear-like behaviors triggered by non-selective CRF receptor agonists, such as CRF and urocortin 1 (Heinrichs \& Richard 1999). Numerous studies showed that activation of $\mathrm{CRF}_{1}$ receptors by stress or CRFrelated peptides promotes anxiety-like behaviors (Takahashi 2001). Hence, several selective $\mathrm{CRF}_{1}$ receptor antagonists were specifically developed for their potential use as anxiolytic agents. All selective $\mathrm{CRF}_{1}$ receptor antagonists developed to date, including SSR125543 (Griebel et al. 2002), CP-154526 (Schulz et al. 1996, Arborelius et al. 2000), CRA1000 (Okuyama et al. 1999), and antalarmin (Deak et al. 1999, Habib et al. 2000, Griebel et al. 2002, Zorrilla et al. 2002) produced anxiolytic-like effects. Considering the role of the $\mathrm{CRF}_{1}$ receptor in the regulation of energy balance, 
these antagonists may also prove useful in the pharmacological treatment of obesity, especially in cases where obesity is associated with hyperactivity of the stress axis.

Animal investigations tend to demonstrate that the $\mathrm{CRF}_{1}$ receptor activity is increased in obesity. Following stressful stimuli, obese rodents showed an enhanced activity of the hypothalamic-pituitary-adrenal (HPA) axis (GuillaumeGentil et al. 1990), which is under the control of the $\mathrm{CRF}_{1}$ receptor. In addition, food-deprived obese Zucker rats exhibit a neurogenic-stress-like response (Timofeeva \& Richard 1997, 2001), which appears to be mediated by the $\mathrm{CRF}_{1}$ receptor and associated with the development of obesity. The development of obesity may be linked to a dysregulation of the HPA axis. In support of this statement, adrenalectomy reverses or attenuates the obese phenotype in genetically obese $(o b / o b)$ mice (Yukimura \& Bray 1978, Feldkircher et al. 1996) and (fa/fa) Zucker rats (Yukimura et al. 1978, Marchington et al. 1983).

This study examines the effects of the $\mathrm{CRF}_{1}$ receptor antagonist, SSR 125543, on energy balance. In order to examine how a sub-chronic treatment with SSR 125543 could block the stress response, Zucker rats were subjected to a 6-h daytime food deprivation, which represents a mild stress in obese Zucker rats. In addition to their hyper-responsive stress axis, obese Zucker rats present several characteristics of the metabolic syndrome including hypertriglyceridemia, hyperinsulinemia, and insulin resistance (Johnson et al. 1991).

\section{Materials and Methods}

\section{Animals and treatments}

Lean $(\mathrm{Fa} /$ ?) and obese $(f a / f a)$ male Zucker rats, aged 8-9 weeks, were purchased from Charles River Laboratories (St-Constant, QC, Canada). All rats were cared for and handled according to the Canadian Guide for the Care and Use of Laboratory Animals, and the protocol was approved by Université Laval Animal Care Committee. The animals were housed individually in wire-bottom cages and, unless specified, allowed unrestricted access to food and water. Throughout the study, rats were given a purified, highcarbohydrate diet, which was composed of the following (in $\mathrm{g} / 100 \mathrm{~g}$ ): $31 \cdot 2$ cornstarch, $31 \cdot 2 \mathrm{DL}$-dextrose, $6 \cdot 4$ soybean oil, $20 \cdot 0$ casein, $0 \cdot 3$ DL-methionine, $1 \cdot 0$ vitamin mix (Teklad no. 40060; Teklad, Madison, WI, USA), 4.9 AIN-93 mineral mix (ICN Biochemicals, Montréal, QC, Canada), and 5.0 fiber (Alphacel; ICN Biochemicals). The energy content of the diet consisted of $64 \cdot 9 \%$ carbohydrate, $14 \cdot 5 \%$ fat, and $20 \cdot 6 \%$ protein, and its density was $4 \cdot 01 \mathrm{kcal} / \mathrm{g}$. Rats were subjected to a $12 \mathrm{~h}$ light:12 h darkness cycle (lights on between 0700 and $1900 \mathrm{~h}$ ) and kept under an ambient temperature of $23 \pm 1{ }^{\circ} \mathrm{C}$. Treated rats received two daily oral administrations of SSR125543 (Sanofi-Aventis, Paris, France) for 21 days; $10 \mathrm{mg} / \mathrm{kg}$ at $0830 \mathrm{~h}$ and $20 \mathrm{mg} / \mathrm{kg}$ at $1600 \mathrm{~h}$. On the last day of treatment, $30 \mathrm{mg} / \mathrm{kg}$ SSR 125543 was administered $4 \mathrm{~h}$ prior to killing. SSR 125543 was suspended in $0.6 \%$ methyl cellulose containing $0.5 \%$ Tween 80 for the first 14 days and in 5\% DMSO, 5\% Cremophor EL, and $90 \%$ saline for the last 7 days of treatment. Rats were killed between 1400 and $1700 \mathrm{~h}$ in either an ad libitum fed state or after a 6 -h food deprivation. Lean and obese rats were anesthetized with 2 and $4 \mathrm{ml}$ of a mixture containing $20 \mathrm{mg} / \mathrm{ml}$ ketamine and $2.5 \mathrm{mg} / \mathrm{ml}$ xylazine respectively. Blood was collected by intracardial puncture into syringes coated with $0.5 \mathrm{M}$ EDTA (Sigma-Aldrich), and rats were perfused intracardially for $2 \mathrm{~min}$ with ice-cold isotonic saline. Brain and interscapular BAT were sampled immediately after the perfusion. BAT was frozen in liquid nitrogen and stored at $-86{ }^{\circ} \mathrm{C}$.

\section{Gains in energy, fat and protein}

Carcasses were autoclaved at $125 \mathrm{kPa}$ for $15 \mathrm{~min}$, homogenized in two volumes of water (w/v) and freeze-dried. Carcass energy content was determined by adiabatic bomb calorimetry, whereas carcass protein was determined using a FP-2000 Nitrogen Analyzer (Leco Corporation, St Joseph, MI, USA) with 250-300 mg dehydrated carcasses. Nonprotein matter energy was obtained by subtracting protein energy from total carcass energy. Values of 23.5 and $39.2 \mathrm{~kJ} / \mathrm{g}$ were used for the calculation of the energy content of protein and fat respectively (Webster 1983). Initial energy, fat, and protein contents of the carcasses were estimated from the live body weight of lean and obese rats with reference to a baseline group of rats (six per phenotype) killed at the beginning of the experimental period. Such estimates allow gains in energy, fat, and protein to be determined for the treatment period. Rats in the initial group were identical in every respect (e.g. age and gender) to those of the experimental groups. Food efficiency was expressed as the ratio of energy gain to digestible energy intake multiplied by 100 .

\section{Plasma determinations}

Blood was harvested by cardiac puncture, centrifuged $\left(1500 \mathrm{~g}, 15 \mathrm{~min}\right.$ at $\left.4{ }^{\circ} \mathrm{C}\right)$, and plasma was stored at $-20^{\circ} \mathrm{C}$ until later biochemical measurements. Plasma glucose concentrations were determined using an automated glucose analyzer YSI 2300 Stat Plus (YSI Incorporated, Yellow Springs, OH, USA). Commercially available RIA kits were used to determine plasma levels of corticosterone (MP Biomedicals, Toronto, ON, Canada) and insulin (Linco Research, St Charles, MO, USA), whereas enzymatic kits were used for triglycerides (Roche) and non-esterified fatty acids (NEFAs; Wako Diagnostics, Richmond, VA, USA). The homeostasis model assessment of insulin resistance (HOMA-IR) was calculated using plasma glucose and insulin levels of food-deprived rats as previously described (Matthews et al. 1985). 


\section{Brain preparation}

Brains were prepared essentially as previously described (Richard et al. 1996). After their removal, brains were placed into a $4 \%$ paraformaldehyde $-3 \cdot 8 \%$ borax solution for at least 7 days with frequent replacement of the solution. They were then transferred to a paraformaldehyde-borax solution containing $10 \%$ sucrose at least $12 \mathrm{~h}$ before cutting them into $30 \mu \mathrm{m}$ thick coronal sections using a sliding microtome (HM 440E; Microm, Walldorf, Germany). Brain sections taken from the olfactory bulb to the brainstem were allocated to six sequential sets in 24-well tissue culture plates containing a cold sterile cryoprotecting solution $(50 \mathrm{mM}$ sodium phosphate buffer, 30\% ethylene glycol, and 20\% glycerol) and stored at $-30{ }^{\circ} \mathrm{C}$.

\section{In situ hybridization histochemistry}

In situ hybridization histochemistry was used to determine c-fos, CRF, and $\mathrm{CRF}_{1}$ receptor mRNA levels on tissue sections taken from the hypothalamus. The protocol, largely adapted from Simmons et al. (1989), is described in detail in Doyon et al. (2006). Briefly, brain sections (one out of every six sections) were fixed in paraformaldehyde (4\%), digested with proteinase $\mathrm{K}$ and acetylated with acetic anhydride prior to hybridization with an antisense ${ }^{35} \mathrm{~S}$-labeled cRNA probe $\left(10^{6}\right.$ c.p.m./slide). After exposure on an X-ray film (Eastman Kodak), slides were exposed in NTB2 nuclear emulsion (Eastman Kodak) for 4 (CRF), 5 (c-fos), or $22\left(\mathrm{CRF}_{1}\right.$ receptor) days. Processed slides were examined by dark-field microscopy using an Olympus BX51 microscope (Olympus America Inc., Melville, NY, USA). Images were acquired with an Evolution QEi camera and analyzed with ImagePro plus v. 5.0.1.11 (MediaCybernetics, Silver Spring, USA). The system was calibrated for each set of analyses to prevent saturation of the integrated signal. Mean pixel densities were obtained by taking measurements from both hemispheres of one to four brain sections and subtracting background readings taken from areas immediately surrounding the region analyzed.

\section{Antisense ${ }^{35}$ S-labeled riboprobes}

Complementary RNA probes were generated from rat cDNA fragments for c-fos (Dr I Verma, The Salk Institute, La Jolla, CA, USA; GenBank accession no. V00727), CRF (Dr K Mayo, North-western University, Evanston, IL, USA), and $\mathrm{CRF}_{1}$ receptor (Dr $\mathrm{MH}$ Perrin and Dr W W Vale, The Clayton Foundation, La Jolla, CA, USA; GenBank accession no. L24096). Radiolabeled antisense riboprobes were synthesized by incubating $250 \mathrm{ng}$ linearized plasmid at $37^{\circ} \mathrm{C}$ for $60 \mathrm{~min}$ in the presence of $10 \mathrm{mM} \mathrm{NaCl}, 10 \mathrm{mM}$ dithiothreitol, $6 \mathrm{mM} \mathrm{MgCl}_{2}, 40 \mathrm{mM}$ Tris (pH 7.9), $0.2 \mathrm{mM}$ ATP/GTP/CTP, $\boldsymbol{\alpha}_{-}{ }^{35} \mathrm{~S}-\mathrm{UTP}, 40 \mathrm{U}$ RNase inhibitor (Roche), and $20 \mathrm{U} \mathrm{T7}$ (c-fos and $\mathrm{CRF}_{1}$ receptor) or SP6 (CRF) RNA polymerase (Promega). The DNA templates were treated with $100 \mu \mathrm{l}$ DNase solution $(1 \mu \mathrm{l}$ DNase, $5 \mu \mathrm{l}$ of $5 \mathrm{mg} / \mathrm{ml}$ tRNA, $94 \mu \mathrm{l}$ of $10 \mathrm{mM}$ Tris/10 mM $\mathrm{MgCl}_{2}$ ). Riboprobes were purified on RNeasy Mini Spin Columns (Qiagen).

\section{Real-time quantitative RT-PCR}

Total RNA was isolated from $60-90 \mathrm{mg}$ BAT using the RNeasy Lipid Tissue Mini Kit (Qiagen) and on-column DNA digestion was performed using the RNase-free DNase Set (Qiagen). First-strand cDNA was synthesized from $1 \mu \mathrm{g}$ total RNA with Expand Reverse Transcriptase and oligo(dT) (Roche). Rat uncoupling protein-1 (UCP1) and L27 amplicons were generated using the primers and the method previously described (Doyon et al. 2006). Amplification was carried out using Platinum Taq polymerase (Invitrogen), CYBR Green I (Cedarlane Laboratories, Hornby, ON, USA), and a Rotor Gene 3000 (Corbett Research, Sydney, Australia). Results were analyzed using Rotor-gene v. 6.0 software (Corbett Research).

\section{Statistical analysis}

Results are presented as mean values \pm 1 s.E.M. Statistical differences in cumulative weight gain between control and SSR 125543-treated rats were determined within each genotype using a crossed-nested design with repeated measurements. Cumulative weight gain data were log transformed and multivariate normality was verified with Mardia's test. Statistical differences within each genotype were determined by Student's $t$-test or two-way ANOVA. Data for corticosterone, insulin, and c-fos mRNA were log transformed, whereas a square root transformation was used for NEFA. Tukey's multiple comparison tests followed two-way ANOVAs with significant interaction effect. Results were considered significant with $P<0 \cdot 05$. Statistical analyses were performed using SAS v. 9.1.3 software package (SAS Institute, Cary, NC, USA) or SigmaStat v. 2.0 software (SPSS, Chicago, IL, USA).

\section{Results}

\section{Body weight and energy balance}

Treatment with the $\mathrm{CRF}_{1}$ receptor antagonist, SSR125543, significantly increased cumulative body weight gain in obese rats (Fig. 1). The difference in cumulative body weight gain between treated and untreated obese rats increased throughout the study to reach $25 \mathrm{~g}$ at the end of the study. Despite the fact that they were heavier than their untreated counterparts, treated obese rats did not exhibit any marked changes in energy balance variables. Protein gain was nonetheless significantly increased (Table 1). One might argue that this increase contributed to the accelerated body weight gain of the treated obese rats. It is noteworthy that changes in protein gain may substantially impact on the body weight gain as they 


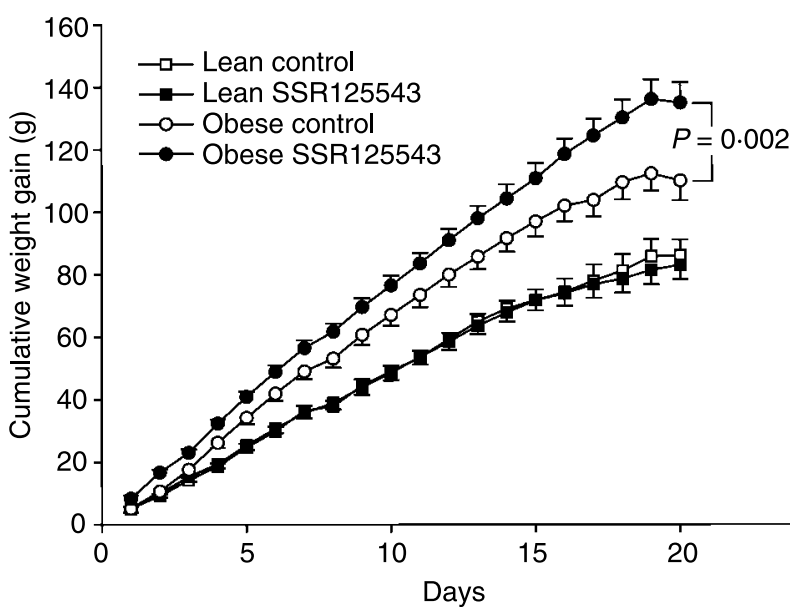

Figure 1 Cumulative weight gain in lean (Fa/?) and genetically obese ( $\mathrm{fa} / \mathrm{fa}$ ) Zucker rats during 20 days of daily oral administration of $30 \mathrm{mg} / \mathrm{kg}$ SSR125543. Significant effect of SSR125543 treatment was assessed by repeated-measures ANOVA. $n=14 /$ group.

are associated with the changes in body water. SSR 125543 significantly increased the BAT UCP1 mRNA levels without significantly affecting energy expenditure or food efficiency.

Although SSR125543 did not affect weight gain (Fig. 1), total energy and fat gains were reduced in lean rats (Table 1). These results further underline the notion that the sole measurement of body weight cannot infallibly predict changes in energy balance, in particular if fat mass is affected, and they strengthen the usefulness of energy balance measurements based on carcass analyses. There was no difference in the protein gain between treated and untreated lean rats. In lean rats, SSR 125543 also reduced food efficiency (19\%), while it did not significantly affect energy expenditure or BAT UCP1 mRNA levels (Table 1).

\section{Metabolic plasma variables}

Treatment with SSR 125543 reduced circulating triglyceride levels in lean rats (Table 2). The fasting-induced reduction in plasma triglycerides was abolished by SSR 125543 in obese rats. Circulating NEFAs were increased following food deprivation, but this increase was blunted by SSR 125543 in obese rats (Table 2). Circulating glucose levels in SSR125543-treated obese rats were reduced to values similar to those of lean and untreated food-deprived obese rats (Table 2). Although SSR 125543 did not significantly modify plasma insulin levels (Table 2), the HOMA-IR index was reduced in obese rats (Table 2). Both antagonist and food deprivation reduced circulating leptin levels in lean but not in obese rats (Table 2). This reduction in leptin levels was consistent with the reduction in fat mass observed in treated lean rats.

\section{The HPA axis and neuronal activation}

Blockade of $\mathrm{CRF}_{1}$ receptors reduced plasma corticosterone levels in lean rats (Fig. 2A). To assess the ability of SSR125543 to attenuate HPA axis and neuronal activation, we measured plasma corticosterone and hypothalamic c-fos expression in food-deprived obese Zucker rats, which are known to exhibit a stress response to short-term food deprivation. Expression of c-fos has been shown to be particularly reliable to assess neuronal activations induced by stressful events (Imaki et al. 1992, Timofeeva \& Richard 2001). The present results demonstrate the ability of SSR 125543 to prevent the fasting-induced increase in corticosterone levels in obese rats (Fig. 2A). Treatment with SSR 125543 also prevented the fasting-induced increase in c-fos mRNA levels in the parvocellular division of the paraventricular hypothalamic nucleus (PVN) of obese Zucker rats (Fig. 2B). C-fos expression in the parvocellular division of the PVN certainly represents one of the most reliable and valid markers of an increase in HPA axis activity. Blockade of the $\mathrm{CRF}_{1}$ receptor increased CRF mRNA levels in the PVN of both lean and obese rats (Fig. 2C and E) but had no effect on $\mathrm{CRF}_{1}$ receptor mRNA levels (Fig. 2D). SSR125543 reduced c-fos mRNA levels in the arcuate nucleus of obese Zucker rats (Fig. 2F).

Table 1 Energy balance and body composition in lean ( $\mathrm{Fa} /$ ? $)$ and genetically obese ( $\mathrm{fa} / \mathrm{fa}$ ) Zucker rats after 21 days of daily oral administration of $30 \mathrm{mg} / \mathrm{kg}$ SSR125543

\begin{tabular}{|c|c|c|c|c|}
\hline & \multicolumn{2}{|l|}{ Lean } & \multicolumn{2}{|l|}{ Obese } \\
\hline & Control & SSR125543 & Control & SSR125543 \\
\hline DEI (kJ) & $6822 \pm 171$ & $6587 \pm 127$ & $10780 \pm 432$ & $9993 \pm 184$ \\
\hline Energy gain $(\mathrm{kJ})$ & $1738 \pm 108$ & $1361 \pm 105 *$ & $3758 \pm 202$ & $3785 \pm 256$ \\
\hline Energy expenditure (kJ) & $5084 \pm 113$ & $5225 \pm 98$ & $7021 \pm 476$ & $6208 \pm 202$ \\
\hline Food efficiency (\%) & $25 \cdot 3 \pm 1 \cdot 3$ & $20 \cdot 5 \pm 1 \cdot 4 *$ & $35 \cdot 5 \pm 2 \cdot 1$ & $37 \cdot 6 \pm 2 \cdot 4$ \\
\hline Fat gain $(\mathrm{g})$ & $34 \cdot 9 \pm 2 \cdot 4$ & $25 \cdot 2 \pm 2 \cdot 4 *$ & $91 \cdot 6 \pm 5 \cdot 0$ & $89 \cdot 9 \pm 6 \cdot 5$ \\
\hline Protein gain (g) & $15 \cdot 8 \pm 0 \cdot 9$ & $15 \cdot 9 \pm 0 \cdot 7$ & $7 \cdot 1 \pm 0 \cdot 8$ & $11 \cdot 1 \pm 0.9 *$ \\
\hline BAT weight $(\mathrm{g})$ & $0.79 \pm 0.03$ & $0 \cdot 77 \pm 0 \cdot 04$ & $1 \cdot 65 \pm 0 \cdot 08$ & $1 \cdot 61 \pm 0 \cdot 07$ \\
\hline BAT UCP1 mRNA & $98 \cdot 5 \pm 11 \cdot 0$ & $95 \cdot 3 \pm 7 \cdot 2$ & $50 \cdot 8 \pm 4 \cdot 7$ & $71 \cdot 2 \pm 7 \cdot 1 *$ \\
\hline
\end{tabular}

Digestible energy intake (DEI) represents $95 \cdot 5 \%$ of total energy intake. Brown adipose tissue (BAT) uncoupling protein-1 (UCP1) mRNA levels are expressed as a ratio of L27 mRNA levels. *Student's $t$-test, $P<0 \cdot 05, n=12-14$ /group. 
Table 2 Plasma glucose, lipids, and hormones in ad libitum fed (AL) and 6-h food-deprived (FD) lean (Fa/?) and genetically obese (fa/fa) Zucker rats after 21 days of daily oral administration of $30 \mathrm{mg} / \mathrm{kg} \mathrm{SSR} 125543$

\begin{tabular}{|c|c|c|c|c|}
\hline & \multicolumn{2}{|l|}{ Control } & \multicolumn{2}{|l|}{ SSR125543 } \\
\hline & $\mathrm{AL}$ & FD & $\mathrm{AL}$ & FD \\
\hline \multicolumn{5}{|l|}{ Lean } \\
\hline Glucose $(\mathrm{mmol} / \mathrm{l})$ & $11 \cdot 6 \pm 0 \cdot 6$ & $11 \cdot 0 \pm 0 \cdot 6$ & $10 \cdot 8 \pm 0 \cdot 7$ & $10 \cdot 5 \pm 0 \cdot 7$ \\
\hline Insulin $(\mathrm{nmol} / \mathrm{l})$ & $0 \cdot 29 \pm 0.06$ & $0 \cdot 16 \pm 0.02^{\dagger}$ & $0 \cdot 21 \pm 0 \cdot 05$ & $0 \cdot 11 \pm 0.02^{+}$ \\
\hline HOMA-IR & n.a. & $12 \cdot 9 \pm 1 \cdot 9$ & n.a. & $8 \cdot 8 \pm 1 \cdot 2$ \\
\hline Triglycerides (mmol/l) & $3 \cdot 58 \pm 0 \cdot 56$ & $2 \cdot 48 \pm 0 \cdot 22^{\dagger}$ & $2 \cdot 51 \pm 0 \cdot 26^{*}$ & $1 \cdot 57 \pm 0.13^{*^{+}}$ \\
\hline NEFA $(\mathrm{mmol} / \mathrm{l})$ & $0.14 \pm 0.03$ & $0.25 \pm 0.02^{+}$ & $0 \cdot 11 \pm 0 \cdot 01$ & $0 \cdot 19 \pm 0 \cdot 02^{+}$ \\
\hline Leptin (ng/ml) & $10 \cdot 0 \pm 0 \cdot 8$ & $7 \cdot 7 \pm 0 \cdot 4^{+}$ & $6 \cdot 6 \pm 0 \cdot 4^{*}$ & $5 \cdot 2 \pm 0 \cdot 4^{*}$ \\
\hline \multicolumn{5}{|l|}{ Obese } \\
\hline Glucose $(\mathrm{mmol} / \mathrm{l})$ & $24 \cdot 6 \pm 1 \cdot 1$ & $14 \cdot 5 \pm 2 \cdot 6^{\S}$ & $12 \cdot 6 \pm 1 \cdot 4^{\ddagger}$ & $13 \cdot 9 \pm 1 \cdot 8$ \\
\hline Insulin $(\mathrm{nmol} / \mathrm{l})$ & $2 \cdot 66 \pm 0 \cdot 30$ & $1 \cdot 64 \pm 0 \cdot 32^{+}$ & $2 \cdot 07 \pm 0 \cdot 43$ & $1 \cdot 25 \pm 0 \cdot 19^{\dagger}$ \\
\hline HOMA-IR & n.a. & $193 \cdot 9 \pm 30 \cdot 1$ & n.a. & $119 \cdot 6 \pm 13 \cdot 6^{*}$ \\
\hline Triglycerides (mmol/l) & $4 \cdot 77 \pm 1 \cdot 03$ & $2 \cdot 26 \pm 0 \cdot 57^{\S}$ & $4 \cdot 34 \pm 0 \cdot 73$ & $3 \cdot 98 \pm 0 \cdot 48^{\ddagger}$ \\
\hline NEFA $(\mathrm{mmol} / \mathrm{l})$ & $0 \cdot 22 \pm 0 \cdot 02$ & $0.54 \pm 0.06^{+}$ & $0.22 \pm 0.02 *$ & $0 \cdot 33 \pm 0 \cdot 04^{*^{+}}$ \\
\hline Leptin (ng/ml) & $40 \cdot 7 \pm 2 \cdot 0$ & $41 \cdot 3 \pm 2 \cdot 0$ & $40 \cdot 8 \pm 0 \cdot 9$ & $38 \cdot 9 \pm 2 \cdot 2$ \\
\hline
\end{tabular}

*Significant main effect of SSR125543 treatment and ${ }^{\dagger}$ significant main effect of food deprivation as assessed by two-way ANOVA or Student's $t$-test (HOMA-IR). When significant, only interaction results are shown: ${ }^{\ddagger}$ significant effect of SSR125543 within a specific feeding status and ${ }^{\S}$ significant effect of food deprivation within a specific treatment. $P<0 \cdot 05, n=6-7 /$ group.

\section{Discussion}

The present study was carried out to assess the effects of the $\mathrm{CRF}_{1}$ receptor antagonist, SSR 125543, on energy balance and food deprived HPA axis, and neuronal activation in obese rats. Overall, SSR 125543 treatment induced mild but rather beneficial effects on energy metabolism; it reduced energy and fat gains in lean rats, while it reduced circulating glucose levels and the HOMA-IR in obese rats. Consistent with reduced fat gain, circulating triglyceride and leptin levels were reduced in SSR125543-treated lean rats. $\mathrm{CRF}_{1}$ receptor blockade increased uncoupling protein-1 mRNA levels in interscapular BAT of obese rats. In obese rats, an increase in protein was observed, which might have contributed to improve overall glucose metabolism. SSR 125543 reduced plasma corticosterone levels in lean rats, prevented corticosterone response to fasting in obese rats, and increased CRF mRNA levels in the PVN of both lean and obese rats, confirming that the antagonist partially blocked $\mathrm{CRF}_{1}$ receptors.

In lean rats, $\mathrm{CRF}_{1}$ receptor blockade reduced total energy and fat gains without significantly affecting the body weight gain. In similar studies, administration of antalarmin (Bornstein et al. 1998) or CRA1000 (Ohata et al. 2002) did not significantly modify body weight in Sprague-Dawley or Wistar rats respectively, although no attempt was made to estimate fat gain. It is noteworthy that reductions in fat gains are not always associated with significant changes in the body weight gains, especially when they are slight and not accompanied with concomitant reductions in protein gain. In this study, protein gains in lean control and SSR 125543treated rats were comparable. Not surprisingly, fat gain reduction in SSR125543-treated rats was paralleled with a significant decrease in the levels of the adipocyte-derived hormone leptin. Changes in leptin levels have repeatedly been reported to follow fat mass alterations (Frederich et al. 1995, Maffei et al. 1995, Considine et al. 1996, Kolaczynski et al. 1996). As opposed to our observation, 11 days of treatment with antalarmin did not modify plasma leptin levels in Sprague-Dawley rats (Bornstein et al. 1998). This discrepancy may be attributable to the shorter treatment period in the antalarmin study. The reduction in fat mass was due to a reduction in food efficiency. As plasma corticosterone promotes fat deposition while increasing energy intake and reducing energy expenditure (Castonguay et al. 1986, Freedman et al. 1986, Strack et al. 1995), lower corticosterone levels in SSR125543-treated lean rats may certainly explain part of the reduction in fat gain.

In obese rats, $\mathrm{CRF}_{1}$ receptor blockade alters neither the body fat gain nor the circulating leptin levels. However, the body weight gain was increased following treatment with SSR 125543. This increase was associated with and was likely accounted for by an increase in the body protein gain. In contrast with changes in fat gain, changes in protein gain are likely to impact more substantially on the body weight gain as they are associated with changes in body water. Changes in protein gain have, however, a lesser influence on energy gain than fat gain changes, since the energy density of protein is lower than that of fat (Webster 1983). The positive effect of the $\mathrm{CRF}_{1}$ receptor antagonist on protein gain may relate to the suppressive effect of this class of compounds on stressinduced activation of corticosterone release. Corticosteroids exert strong catabolic effects on protein mass (Hasselgren 1999). Although SSR 125543 did not normalize plasma corticosterone in obese rats, it nonetheless blunted the elevation of corticosterone levels following food deprivation, which represents a stressing condition in obese Zucker rats (Timofeeva \& Richard 1997, 2001). The high basal levels of corticosterone in obese rats possibly prevent a complete 
A

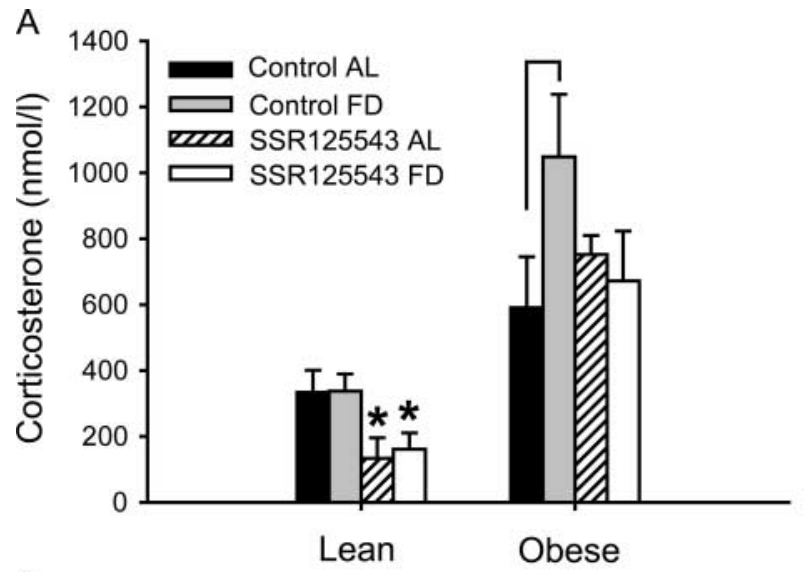

C

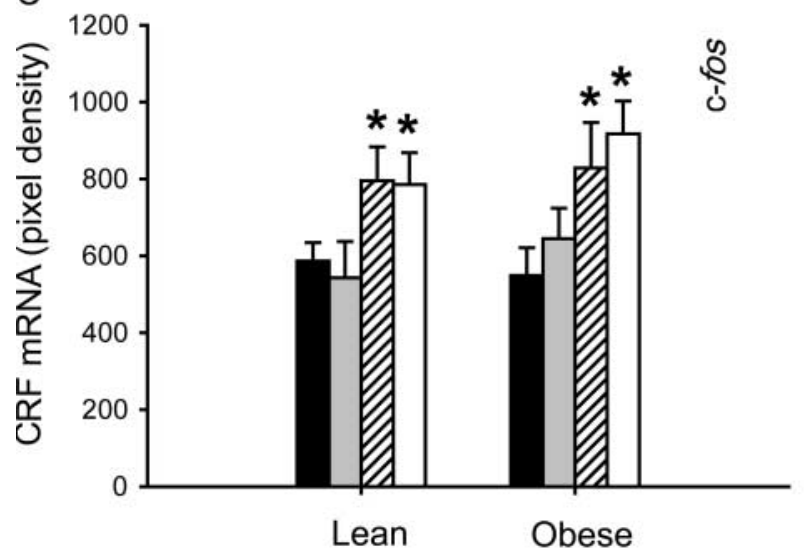

E

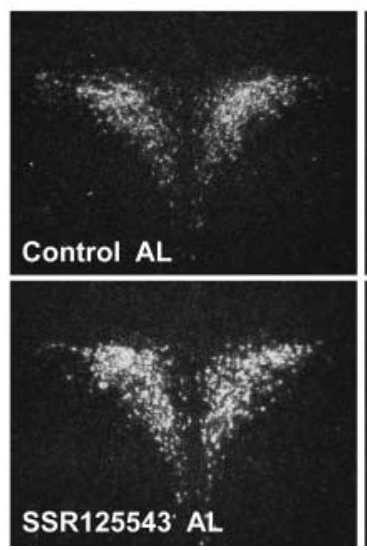

$\mathrm{B}$

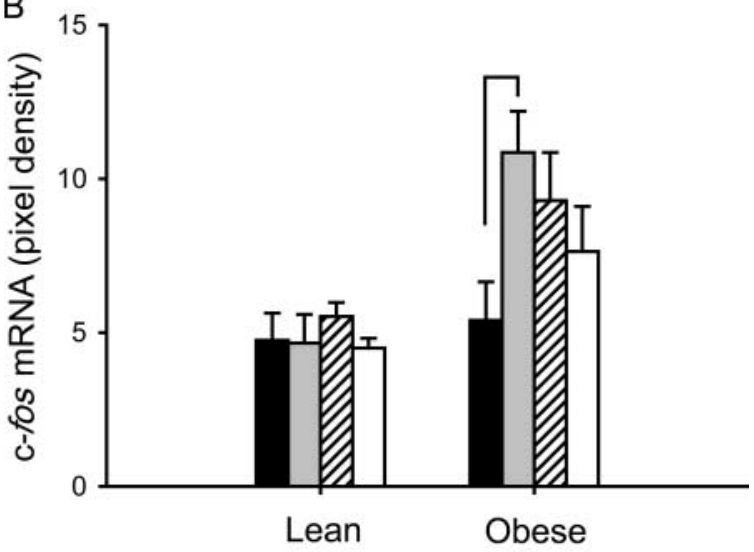

$\mathrm{D}$

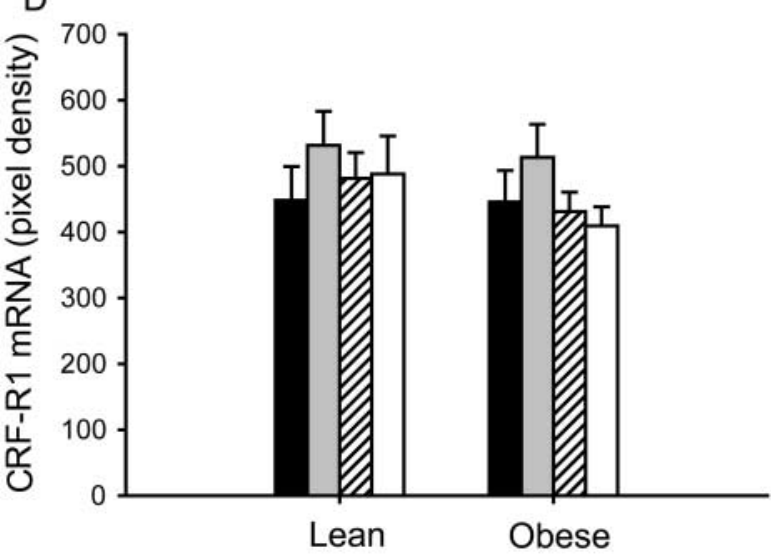

$\mathrm{F}$

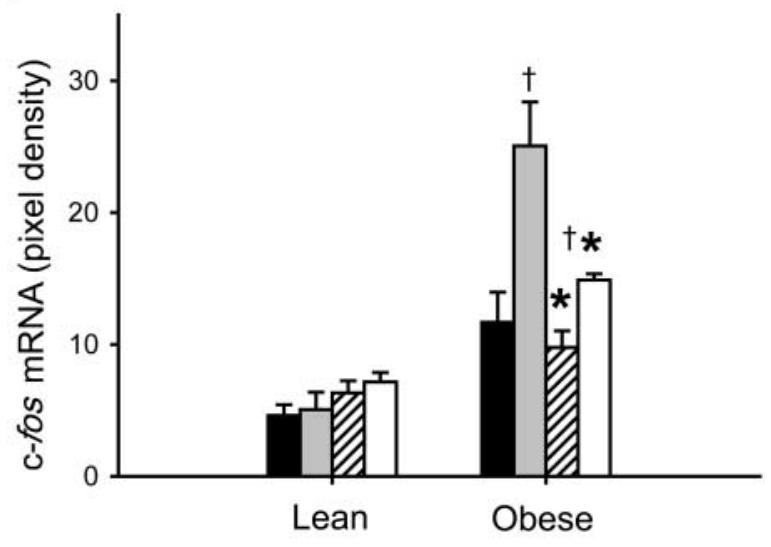

Figure 2 Plasma corticosterone (A), and mean pixel density of the hybridization signal for C-fos (B), corticotropin-releasing factor (CRF) (C) and $\mathrm{CRF}_{1}$ receptor (CRF-R1) (D) mRNA in the parvocellular division of the paraventricular hypothalamic nucleus (PVN), and c-fos mRNA in the arcuate nucleus (F) of ad libitum fed (AL) and 6-h food-deprived (FD) lean (Fa/?) and genetically obese (fa/fa) Zucker rats after 21 days of daily oral administration of $30 \mathrm{mg} / \mathrm{kg}$ SSR125543. Representative hybridization signals for CRF mRNA in the PVN of obese rats (E).

*Significant main effect of SSR125543 treatment and ${ }^{+}$significant main effect of food deprivation as assessed by two-way ANOVA. When significant, only interaction results are shown (bars), as assessed by Tukey's multiple comparison tests. $P<0 \cdot 05, n=6-7 / g r o u p$.

restoration of the body protein gain to the lean levels. Also consistent with a reduction in the HPA axis activity tone in obese rats treated with SSR 125543 is the increased levels of BAT UCP1 mRNA. We previously showed that corticosterone reduces BAT UCP1 mRNA levels (Arvaniti et al. 1998). In addition, BAT thermogenic activity is decreased by corticosterone and increased by adrenalectomy or treatment with the glucocorticoid receptor antagonist 
RU-486 (Galpin et al. 1983, Hardwick et al. 1989, Strack et al. 1995). The increase in UCP1 expression in obese SSR 125543-treated rats has probably contributed to sustain the energy efficiency despite the substantial (though not statistically significant) energy intake that occurred in these rats. UCP1 is unique to BAT and confers thermogenic properties to this tissue (Sell et al. 2004).

The obese Zucker rat is hyperinsulinemic (Zucker \& Antoniades 1972) and presents a mild hyperglycemia (Triscari et al. 1979). Here, we show that SSR 125543 restored normal glycemia in obese rats. This result is in agreement with the hyperglycemic effect of central CRF administration (Brown et al. 1982a,b). Although the reduction in insulin levels did not reach statistical significance, the HOMA-IR index was reduced in obese rats, indicating improved insulin sensitivity. Reduced fat gain in SSR125543-treated lean rats was associated with a reduction in circulating triglyceride that was not seen in treated obese rats, which did not exhibit a reduction in fat gain. However, SSR 125543 prevented the fasting-induced reduction in circulating triglycerides and blunted the fasting-induced increase in NEFA in obese rats. Together, these results indicate that $\mathrm{CRF}_{1}$ receptor blockade improves plasma variables related to diabetes.

The action of CRF-related peptides on HPA axis activity is thought to be almost exclusively mediated through the $\mathrm{CRF}_{1}$ receptor (Doyon et al. 2004). As expected, $\mathrm{CRF}_{1}$ receptor blockade attenuated the activity of the HPA axis. Three weeks of treatment with SSR 125543 reduced the basal plasma corticosterone levels in lean rats and prevented the fastinginduced corticosterone response in obese Zucker rats, which are hypercorticosteronemic (Guillaume-Gentil et al. 1990, Richard et al. 1996) and hypersensitive to stress (GuillaumeGentil et al. 1990, Timofeeva \& Richard 1997). Similarly, a previous study showed that SSR 125543 reduced the basal adrenocorticotropic hormone (ACTH) concentrations and attenuated the CRF- and stress-induced increase in circulating ACTH in Sprague-Dawley rats (Gully et al. 2002). However, sub-chronic administration of CRA1000 (Ohata et al. 2002) or antalarmin (Wong et al. 1999) did not blunt the HPA response to immobilization stress. The relatively mild nature of the stressor used in our study (6-h daytime food deprivation) may explain the discrepancy with other subchronic studies.

Centrally, SSR125543 increased CRF mRNA levels in the parvocellular division of the PVN of both lean and obese Zucker rats, which likely resulted from an attenuation of the negative feedback regulation of CRF synthesis by corticosterone (Jingami et al. 1985, Young et al. 1986, Herman et al. 1992, Arvaniti et al. 2001). Consistent with the corticosterone results, $\mathrm{CRF}_{1}$ receptor blockade prevented the fastinginduced increase in c-fos mRNA levels in the PVN of obese rats. SSR 125543 also reduced c-fos mRNA levels in the arcuate nucleus of obese rats. These results imply that the $\mathrm{CRF}_{1}$ receptor is involved in stress-induced neuronal activation. Despite changes in c-fos mRNA levels in the arcuate nucleus, we observed no changes in neuropeptide $\mathrm{Y}$, agouti-related peptide, or proopiomelanocortin mRNA levels in this brain region (data not shown).

In conclusion, our results show that although SSR 125543 had relatively mild effects on energy balance, blockade of $\mathrm{CRF}_{1}$ receptors attenuated several metabolic effects of shortterm fasting and improved plasma variables related to the metabolic syndrome and diabetes.

\section{Acknowledgements}

We wish to thank Sanofi-Aventis for providing SSR 125543. This work was supported by a grant from Instituts de recherche en santé du Canada (IRSC) (to D Richard) and a postdoctoral fellowship from Fonds québécois de la recherche sur la nature et les technologies (FQRNT) (to C Doyon). The authors declare that there is no conflict of interest that would prejudice the impartiality of this scientific work.

\section{References}

Arase K, York DA, Shimizu H, Shargill N \& Bray GA 1988 Effects of corticotropin-releasing factor on food intake and brown adipose tissue thermogenesis in rats. American Journal of Physiology 255 E255-E259.

Arborelius L, Skelton KH, Thrivikraman KV, Plotsky PM, Schulz DW \& Owens MJ 2000 Chronic administration of the selective corticotropinreleasing factor 1 receptor antagonist CP-154,526: behavioral, endocrine and neurochemical effects in the rat. Journal of Pharmacology and Experimental Therapeutics 294 588-597.

Arvaniti K, Ricquier D, Champigny O \& Richard D 1998 Leptin and corticosterone have opposite effects on food intake and the expression of UCP1 mRNA in brown adipose tissue of lepob/lepob mice. Endocrinology 139 4000-4003.

Arvaniti K, Huang Q \& Richard D 2001 Effects of leptin and corticosterone on the expression of corticotropin-releasing hormone, agouti-related protein, and proopiomelanocortin in the brain of ob/ob mouse. Neuroendocrinology 73 227-236.

Bornstein SR, Webster EL, Torpy DJ, Richman SJ, Mitsiades N, Igel M, Lewis DB, Rice KC, Joost HG, Tsokos M et al. 1998 Chronic effects of a nonpeptide corticotropin-releasing hormone type I receptor antagonist on pituitary-adrenal function, body weight, and metabolic regulation. Endocrinology 139 1546-1555.

Brown MR, Fisher LA, Rivier J, Spiess J, Rivier C \& Vale W $1982 a$ Corticotropin-releasing factor: effects on the sympathetic nervous system and oxygen consumption. Life Sciences 30 207-210.

Brown MR, Fisher LA, Spiess J, Rivier C, Rivier J \& Vale W $1982 b$ Corticotropin-releasing factor: actions on the sympathetic nervous system and metabolism. Endocrinology 111 928-931.

Castonguay TW, Dallman MF \& Stern JS 1986 Some metabolic and behavioral effects of adrenalectomy on obese Zucker rats. American Journal of Physiology 251 R923-R933.

Considine RV, Sinha MK, Heiman ML, Kriauciunas A, Stephens TW, Nyce MR, Ohannesian JP, Marco CC, McKee LJ, Bauer TL et al. 1996 Serum immunoreactive-leptin concentrations in normal-weight and obese humans. New England Journal of Medicine 334 292-295.

Currie PJ, Coscina DV, Bishop C, Coiro CD, Koob GF, Rivier J \& Vale W 2001 Hypothalamic paraventricular nucleus injections of urocortin alter food intake and respiratory quotient. Brain Research 916 222-228.

De Fanti BA \& Martínez JA 2002 Central urocortin activation of sympatheticregulated energy metabolism in Wistar rats. Brain Research 930 37-41. 
Deak T, Nguyen KT, Ehrlich AL, Watkins LR, Spencer RL, Maier SF, Licinio J, Wong ML, Chrousos GP, Webster E et al. 1999 The impact of the nonpeptide corticotropin-releasing hormone antagonist antalarmin on behavioral and endocrine responses to stress. Endocrinology 140 79-86.

Doyon C, Moraru A \& Richard D 2004 The corticotropin-releasing factor system as a potential target for antiobesity drugs. Drug News Perspectives $\mathbf{1 7}$ 505-517.

Doyon C, Denis RG, Baraboi ED, Samson P, Lalonde J, Deshaies Y \& Richard D 2006 Effects of rimonabant (SR141716) on fasting-induced hypothalamicpituitary-adrenal axis and neuronal activation in lean and obese Zucker rats. Diabetes 55 3403-3410.

Feldkircher KM, Mistry AM \& Romsos DR 1996 Adrenalectomy reverses pre-existing obesity in adult genetically obese $(\mathrm{ob} / \mathrm{ob})$ mice. International Journal of Obesity and Related Metabolic Disorders 20 232-235.

Frederich RC, Hamann A, Anderson S, Lollmann B, Lowell BB \& Flier JS 1995 Leptin levels reflect body lipid content in mice: evidence for dietinduced resistance to leptin action. Nature Medicine 1 1311-1314.

Freedman MR, Horwitz BA \& Stern JS 1986 Effect of adrenalectomy and glucocorticoid replacement on development of obesity. American Journal of Physiology 250 R595-R607.

Galpin KS, Henderson RG, James WP \& Trayhurn P 1983 GDP binding to brown-adipose-tissue mitochondria of mice treated chronically with corticosterone. Biochemical Journal 214 265-268.

Griebel G, Simiand J, Steinberg R, Jung M, Gully D, Roger P, Geslin M, Scatton B, Maffrand JP \& Soubrié P 2002 4-(2-Chloro-4-methoxy-5methylphenyl)- $N$-[(1S)-2-cyclopropyl-1-(3-fluoro-4- methylphenyl)ethyl]5-methyl-N-(2-propynyl)-1, 3-thiazol-2-amine hydrochloride (SSR125543A), a potent and selective corticotrophin-releasing factor1 receptor antagonist. II. Characterization in rodent models of stress-related disorders. Journal of Pharmacology and Experimental Therapeutics 301 333-345.

Guillaume-Gentil C, Rohner-Jeanrenaud F, Abramo F, Bestetti GE, Rossi GL \& Jeanrenaud B 1990 Abnormal regulation of the hypothalamo-pituitaryadrenal axis in the genetically obese fa/fa rat. Endocrinology 126 1873-1879.

Gully D, Geslin M, Serva L, Fontaine E, Roger P, Lair C, Darre V, Marcy C, Rouby PE, Simiand J et al. 2002 4-(2-Chloro-4-methoxy-5-methylphenyl)-N-[(1S)-2-cyclopropyl-1-(3-fluoro-4- methylphenyl)ethyl]5-methyl$\mathrm{N}$-(2-propynyl)-1,3-thiazol-2-amine hydrochloride (SSR125543A): a potent and selective corticotrophin-releasing factor1 receptor antagonist. Journal of Pharmacology and Experimental Therapeautics 301 322-332.

Habib KE, Weld KP, Rice KC, Pushkas J, Champoux M, Listwak S, Webster EL, Atkinson AJ, Schulkin J, Contoreggi C et al. 2000 Oral administration of a corticotropin-releasing hormone receptor antagonist significantly attenuates behavioral, neuroendocrine, and autonomic responses to stress in primates. PNAS 97 6079-6084.

Hardwick AJ, Linton EA \& Rothwell NJ 1989 Thermogenic effects of the antiglucocorticoid RU-486 in the rat: involvement of corticotropinreleasing factor and sympathetic activation of brown adipose tissue. Endocrinology 124 1684-1688.

Hasselgren PO 1999 Glucocorticoids and muscle catabolism. Current Opinion in Clinical Nutrition and Metabolic Care 2 201-205.

Heinrichs SC \& Richard D 1999 The role of corticotropin-releasing factor and urocortin in the modulation of ingestive behavior. Neuropeptides $\mathbf{3 3}$ 350-359.

Herman JP, Schafer MK, Thompson RC \& Watson SJ 1992 Rapid regulation of corticotropin-releasing hormone gene transcription in vivo. Molecular Endocrinology 6 1061-1069.

Hotta M, Shibasaki T, Arai K \& Demura H 1999 Corticotropin-releasing factor receptor type 1 mediates emotional stress-induced inhibition of food intake and behavioral changes in rats. Brain Research 823 221-225.

Imaki T, Shibasaki T, Hotta M \& Demura H 1992 Early induction of c-fos precedes increased expression of corticotropin-releasing factor messenger ribonucleic acid in the paraventricular nucleus after immobilization stress. Endocrinology 131 240-246.

Jingami H, Matsukura S, Numa S \& Imura H 1985 Effects of adrenalectomy and dexamethasone administration on the level of prepro-corticotropinreleasing factor messenger ribonucleic acid (mRNA) in the hypothalamus and adrenocorticotropin/beta-lipotropin precursor mRNA in the pituitary in rats. Endocrinology 117 1314-1320.
Johnson PR, Greenwood MR, Horwitz BA \& Stern JS 1991 Animal models of obesity: genetic aspects. Annual Review of Nutrition 11 325-353.

Kolaczynski JW, Ohannesian JP, Considine RV, Marco CC \& Caro JF 1996 Response of leptin to short-term and prolonged overfeeding in humans. Journal of Clinical Endocrinology and Metabolism 81 4162-4165.

LeFeuvre RA, Rothwell NJ \& Stock MJ 1987 Activation of brown fat thermogenesis in response to central injection of corticotropin releasing hormone in the rat. Neuropharmacology 26 1217-1221.

Maffei M, Halaas J, Ravussin E, Pratley RE, Lee GH, Zhang Y, Fei H, Kim S, Lallone R, Ranganathan S et al. 1995 Leptin levels in human and rodent: measurement of plasma leptin and ob RNA in obese and weight-reduced subjects. Nature Medicine 1 1155-1161.

Marchington D, Rothwell NJ, Stock MJ \& York DA 1983 Energy balance, diet-induced thermogenesis and brown adipose tissue in lean and obese (fa/fa) Zucker rats after adrenalectomy. Journal of Nutrition 113 1395-1402.

Matthews DR, Hosker JP, Rudenski AS, Naylor BA, Treacher DF \& Turner RC 1985 Homeostasis model assessment: insulin resistance and beta-cell function from fasting plasma glucose and insulin concentrations in man. Diabetologia 28 412-419.

Ohata H, Arai K \& Shibasaki T 2002 Effect of chronic administration of a CRF1 receptor antagonist, CRA1000, on locomotor activity and endocrine responses to stress. European Journal of Pharmacology 457 201-206.

Okuyama S, Chaki S, Kawashima N, Suzuki Y, Ogawa S, Nakazato A, Kumagai T, Okubo T \& Tomisawa K 1999 Receptor binding, behavioral, and electrophysiological profiles of nonpeptide corticotropin-releasing factor subtype 1 receptor antagonists CRA1000 and CRA1001. Journal of Pharmacology and Experimental Therapeutics 289 926-935.

Pelleymounter MA, Joppa M, Carmouche M, Cullen MJ, Brown B, Murphy B, Grigoriadis DE, Ling N \& Foster AC 2000 Role of corticotropin-releasing factor (CRF) receptors in the anorexic syndrome induced by CRF. Journal of Pharmacology and Experimental Therapeutics 293 799-806.

Richard D, Rivest R, Naïmi N, Timofeeva E \& Rivest S 1996 Expression of corticotropin-releasing factor and its receptors in the brain of lean and obese Zucker rats. Endocrinology 137 4786-4795

Richard D, Lin Q \& Timofeeva E 2002 The corticotropin-releasing factor family of peptides and CRF receptors: their roles in the regulation of energy balance. European Journal of Pharmacology 440 189-197.

Schulz DW, Mansbach RS, Sprouse J, Braselton JP, Collins J, Corman M, Dunaiskis A, Faraci S, Schmidt AW, Seeger T et al. 1996 CP-154,526: a potent and selective nonpeptide antagonist of corticotropin releasing factor receptors. PNAS 93 10477-10482.

Sell H, Deshaies Y \& Richard D 2004 The brown adipocyte: update on its metabolic role. International Journal of Biochemistry and Cell Biology 36 20982104.

Simmons DM, Arriza JL \& Swanson LW 1989 A complete protocol for in situ hybridization of messenger RNAs in brain and other tissues with radiolabeled single-stranded RNA probes. Journal of Histotechnology 12 $169-181$.

Smagin GN, Howell LA, Ryan DH, De Souza EB \& Harris RB 1998 The role of CRF2 receptors in corticotropin-releasing factor- and urocortininduced anorexia. Neuroreport 9 1601-1606.

Strack AM, Bradbury MJ \& Dallman MF 1995 Corticosterone decreases nonshivering thermogenesis and increases lipid storage in brown adipose tissue. American Journal of Physiology 268 R183-R191.

Takahashi LK 2001 Role of CRF1 and CRF2 receptors in fear and anxiety. Neuroscience and Biobehavioral Reviews 25 627-636.

Timofeeva E \& Richard D 1997 Functional activation of CRH neurons and expression of the genes encoding $\mathrm{CRH}$ and its receptors in food-deprived lean $(\mathrm{Fa} /$ ?) and obese (fa/fa) Zucker rats Neuroendocrinology 66 327-340.

Timofeeva E \& Richard D 2001 Activation of the central nervous system in obese Zucker rats during food deprivation. Journal of Comparative Neurology $44171-89$

Triscari J, Stern JS, Johnson PR \& Sullivan AC 1979 Carbohydrate metabolism in lean and obese Zucker rats. Metabolism 28 183-189.

Webster AJF 1983 Energetics of maintenance and growth. In Mammalian Thermogenesis, pp 178-207. Eds L Girardier \& M Stock. London: Chapman \& Hall. 
Wong ML, Webster EL, Spokes H, Phu P, Ehrhart-Bornstein M, Bornstein S, Park CS, Rice KC, Chrousos GP, Licinio J et al. 1999 Chronic administration of the non-peptide CRH type 1 receptor antagonist antalarmin does not blunt hypothalamic-pituitary-adrenal axis responses to acute immobilization stress. Life Sciences 65 PL53-PL58.

Young WS 3rd, Mezey E \& Siegel RE 1986 Quantitative in situ hybridization histochemistry reveals increased levels of corticotropin-releasing factor mRNA after adrenalectomy in rats. Neuroscience Letters 70 198-203.

Yukimura Y \& Bray GA 1978 Effects of adrenalectomy on body weight and the size and number of fat cells in the Zucker (fatty) rat. Endocrine Research Communications 5 189-198.

Yukimura Y, Bray GA \& Wolfsen AR 1978 Some effects of adrenalectomy in the fatty rat. Endocrinology 103 1924-1928.
Zorrilla EP, Valdez GR, Nozulak J, Koob GF \& Markou A 2002 Effects of antalarmin, a CRF type 1 receptor antagonist, on anxiety-like behavior and motor activation in the rat. Brain Research 952 188-199.

Zucker LM \& Antoniades HN 1972 Insulin and obesity in the Zucker genetically obese rat 'fatty'. Endocrinology 90 1320-1330.

Received in final form 15 January 2007

Accepted 25 January 2007

Made available online as an Accepted Preprint 26 January 2007 